\title{
PENGARUH WAKTU DAN TEMPERATUR PENGAMBILAN PEKTIN PADA BUAH TOMAT DENGAN CARA EKSTRAKSI
}

\author{
Sukaryo \\ Fakultas Teknik Universitas Pandanaran \\ Jl. Banjarsari Barat No.1 Semarang \\ Email: iyok.sukaryo.yahoo.co.id
}

\begin{abstract}
ABSTRAK
Pektin merupakan salah satu senyawa yang dapat membentuk gel. Pektin adalah salah satu bahan dalam pembuatan jelly, jams, kembang gula, obat-obatan dan kosmetik. Produksi pectin umumnya menggunakan buah apel yang harganya sangat mahal. Salah satu alternatif bahan baku yang digunakan adalah buah tomat (Lycopersium esculentum) yang mempunyai kandungan pektin yang diambil . Pengaruh waktu ekstraksi, suhu ekstraksi dan $\mathrm{pH}$ larutan akan mempengaruhi terambilnya pektin yang diperoleh. Proses ini dilakukan dengan proses ekstraksi dan distilasi untuk pemurniannya. Dengan berat sampel 40 gr, jumlah solvent $200 \mathrm{ml}$ dengan waktu ekstraksi 30 menit, temperatur ekstraksi 84,9 ${ }^{\circ} \mathrm{C}$, pH larutan 1 dan pada tekanan operasi 1 Atm. Diperoleh kadar air dan kadar abu masing-masing 76,2 \% dan 9,03\%. Sedangkan pektin yang diperoleh dari hasil percobaan 2,267 gr dan hasil perhitungan diperoleh pektin sebesar 2,451 gr masing-masing dalam 40 gr tomat. Hasil studi menunjukan bahwa tomat tersebut layak digunakan sebagai sumber bahan produksi pektin.
\end{abstract}

Kata kunci : Pektin, Tomat, Ekstraksi, pengaruh suhu, pengaruh waktu

\section{PENDAHULUAN}

Salah satu senyawa kimia yang mempunyai kemampuan membentuk gel adalah pektin, yang pertama kali ditemukan oleh Vauguelin tahun 1790. Kegunaan pektin antara lain sebagai bahan baku dalam pembuatan jelly, jams, kembang gula, obat-obatan dan juga kosmetik. Di Indonesia pektin merupakan barang yang masih didatangkan dari luar negri. Pada tahun 1995, Negara Indonesia mengimpor pektin sejumlah $601.765 \mathrm{~kg}$ dengan harga mencapai US\$ 621.652, sehingga pektin setiap tahun meningkat (Budiyanto, 2008). Pektin banyak terdapat dalam jaringan tanaman terutama pada buah-buahan (Fitriani 2003). Di negaranegara Eropa dan Amerika, pektin di produksi secara besar-besaran dengan menggunakan bahan baku mayoritas dari buah apel dan jeruk. Apel dan jeruk merupakan jenis buah yang mempunyai nilai jual tinggi. Selain apel dan jeruk, banyak bahanbahan yang mengandung senyawa pektin. Bahanbahan yang mengandung pektin adalah sejenis sayuran dan buah-buahan lain, salah satunya adalah buah tomat. Tomat banyak digemari orang karena rasanya yang enak, segar dan sedikit asam serta mengandung sumber vitamin. Buah ini tidak hanya dikonsumsi secara langsung saja, tetapi juga diambil pektinnya sebagai bahan pembuatan jelly dan jams (Willat at al., 2006). Disamping itu Pektin berguna untuk dehydrating agents, emulsyng agents sehingga dapat digunakan dalam dunia industri.

Tomat ( Lycopersium esculentum ) termasuk suku solanceae, tanaman setahun berbentuk perdu, daunnya bercelah menyirip dan tersusun dalam tangkai bersama. Bentuk buah tomat bermacammacam, ada yang bulat ada yang pipih, ada pula yang berbentuk bola lampu. Indonesia merupakan negara agraris sehingga banyak tumbuh-tumbuhan yang cocok ditanam di negara ini salah satunya buah tomat. Buah tomat merupakan salah satu tanaman yang sangat cocok ditanam di wilayah Indonesia. Baik di dataran rendah maupun dataran tinggi dengan syarat tanahnya gembur dan kandungan pasirnya sedikit. Tomat sebaiknya ditanam dua bulan sebelum hujan berakhir, diharapkan waktu berbuah akan jauh pada permulaan musim kemarau dimana masih ada sedikit hujan. Selain itu di tempat-tempat yang dapat digenangi air seperti sawah (Departemen 
Pertanian , 1977 ). Adapun jenis-jenis tomat antara lain: tomat apel, tomat biasa, tomat kentang dan tomat keriting. Budi daya tomat di wilayah Indonesia sangat mudah yaitu dengan cara menyemaikan bijinya lalu di tanam pada bedengan sesuai dengan aturan dari dinas Pertanian. Produksi buah tomat ini cukup melimpah (Dinas Pertanian Tanaman Pangan, 1992). Pengambilan pektin dari buah tomat untuk menambah daya guna dan menaikan nilai tambah ekonomi buah tomat sebab buah tomat adalah buah yang mudah busuk, dan juga dapat meningkatkan produktivitas lahan pertanian yang masih tidur.

Senyawa pektin merupakan senyawa poli sakarida yang terdispersi dalam air dan merupakan rantai..Unsur penyusun pektin sebagian besar dari asam-asam anhidro galakturonat dimana diperkirakan terdapat kombinasi yang membentuk rantai. Gugus karboksil dari asam poligalakturonat dapat diesterifikasi oleh metol dan dinetralkan dengan basa. $\mathrm{pH}$ yang diizinkan berkisar 2,6 - 2,8 (Kirk dan Othmer, 1958 ). Penggunaan jenis asam akan mempengaruhi sifat pektin yang dihasilkan sebab tingkat hidrolisis dipengaruhi kekuatan atau konsentrasi asam yang akan menghasilkan jenis pektin dengan karakteristik yang berbeda pula (Garna et al., 2007). Gugus metal ester pada molekul pektin ditunjukan banyaknya kadar metoksil (Putra, 2010). Banyaknya metoksil menunjukan banyaknya metal yang teresterifikasi. Kadar metoksil juga dapat mempengaruhi kemampuan dalam pembentukan gel yang baik. Semakin besar kadar metoksilnya, semakin besar pembentukan gelnya (Muhidin, 2001). Kadar metoksil menentukan mutu dari pektin itu sendiri. Jika kadar metoksi antara 2,3 - 4,5\% menujukkan pektin berkadar metoksi rendah sedangkan kadar lebih dari 7,12\% menunjukkan pektin berkadar metoksi tinggi (Rariaty, 2000). Untuk mendapatkan pektin dari buah tomat dapat dilakukan dengan menggunakan proses ekstraksi yaitu proses pemisahan satu atau beberapa bahan dari suatu cairan atau padatan dengan menggunakan pelarut (Cabe, 2005).

\section{METODOLOGI}

\section{Bahan dan alat}

Penelitian dilaksanakan di Laboratorium Universitas Pandanaran Semarang. Bahan utama dalam penelitian ini adalah buah tomat yang diperoleh dari salah satu pasar tradisional di Semarang. Sebelum diambil pektinnya, buah tomat ditumbuk, dicuci dan diperas untuk diambil ektraknya. Bahan kimia yang digunakan adalah larutan $\mathrm{HCl}$, aseton, alkohol dan aquades. Alat yang digunakan adalah labu leher tiga, pendingin, termometer, heater lengkap dengan magnetic stirrer, penangas air, Furnace, stop watch, cawan porselin, neraca digital, desikator dan oven.

\section{Prosedur Analisis Kadar Air}

Dalam menentukan kadar air adalah menggunakan metode Sudarmadji (1989) yaitu dengan memanaskan cawan porselin dalam oven pada suhu $\pm 110^{\circ} \mathrm{C}$ selama 2 jam kemudian dinginkan dalam dexicator dan timbang hingga berat konstan. Sampel 40 gr dimasukan dalam cawan dan panaskan dalam oven pada suhu \pm 100 ${ }^{\circ} \mathrm{C}$ selama 60 menit dan dinginkan. Timbang sampel tersebut untuk mencari kadar airnya.

$$
\text { Kadar air }=\frac{\text { Bearat basah }- \text { berat kering }}{\text { Bearat basah }} \times 100 \%
$$

\section{Prosedur Analisis Kadar Abu}

Kurs porselin dikeringkan selama 2 jam dalam oven pada suhu $\pm 40^{\circ} \mathrm{C}$ didinginkan dan ditimbang, sampel sebanyak 40 gr dimasukan kedalam kurs lalu ditimbang dan dipanaskan diatas api langsung sampai berpijar. Pengabuan dilanjutkan dalam furnice pada suhu $\pm 600{ }^{\circ} \mathrm{C}$ selama 4 jam sampai sampel berubah warna putih, krus dikeluarkan dan didinginkan kemudian di timbang

Kadar abu $=\frac{\text { Berat abu dari sampel }}{\text { Berat sampel }} \times 100 \%$

\section{Prosedur Pengambilan Pektin}

Buah tomat ditumbuk kemudian dicuci dengan air, lalu diperas. Hasil perasan di timbang 40 gr dan diencerkan dengan aquadest hingga 200 ml. Larutan tersebut diatur pH-nya dengan menetesi $\mathrm{HCl} 1 \mathrm{M}$ pada setiap ekstraksi. Setiap bahan yang akan di ekstraksi ditentukan kadar airnya. Sampel diektraksi sesuai dengan variabel yang telah ditentukan yaitu suhu $60{ }^{\circ} \mathrm{C}$ level bawah dan suhu $100{ }^{\circ} \mathrm{C}$ level atas, $\mathrm{pH} 1$ pada level bawah dan $\mathrm{pH}$ 3,5 pada level atas, waktu ekstraksi 30 menit pada level bawah dan 120 menit pada level 
atas. Hasil ekstraksi disaring dalam keadaan panas untuk memisahkan filtrat dari ampasnya. Filtrat hasil penyaringan didinginkan. Setelah dingin, filtrat tersebut ditambah aseton sambil diaduk dengan perbandingan aseton : filtrat sebanyak 1 : 2. Filtrat dan endapan dipisahkan dengan cara disaring dengan kertas saring. Endapan yang terpisah dicuci dengan alkohol. Endapan yang dihasilkan tersebut tersebut merupakan pektin.

\section{Prosedur Analisis Kadar Pektin}

Panaskan krust dalam oven pada suhu \pm 110 ${ }^{\circ} \mathrm{C}$ selama 2 jam dan dinginkan dalam desikator, kemudian timbang sampai berat konstan. Pektin hasil penyaringan masukan dalam krust dan panaskan dalam oven pada suhu $\pm 70{ }^{\circ} \mathrm{C}$ sampai pektin kering, didinginkan dalam decikator lalu timbang sehingga diperoleh pektin kering.

$$
\text { Yield }=\frac{\text { Berat pektin kering }}{\text { Berat pektin basah }} \times 100 \%
$$

\section{Metodologi Eksperimental Design}

Eksperimental design adalah salah satu cara yang sering digunakan karena membutuhkan jumlah minimum yang sedikit untuk mengetahui efek-efek pada semua variabel. Eksperimental design mempunyai beberapa cara, salah satunya disebut dengan metode fraksional factorial design dengan dua level yaitu level tinggi dan level rendah. Hasil pengamatan dari eksperimental design awal digunakan untuk menentukan variabel yang sangat berpengaruh dalam penentuan satu variabel utama yang dilakukan secara bertahap dengan factorial design. Pada setiap rancangan beberapa variabel tertentu yaitu yang berpengaruh kecil pada hasil produk dihilangkan atau di reduksi hingga didapat satu variabel akhir yang paling berpengaruh karena pada setiap rancangan baru disusun harga-harga variabel baru untuk peningkatan hasil. Pada akhir penelitian akan dapat hasil atau kondisi operasi yang paling optimal untuk semua variabel tanpa menghilangkan efek kontraksinya.

Pada penelitian ini menggunakan metode faktorial design design dengan 3 variabel berubah, maka dalam percobaan ini efek utama tiap-tiap percobaan diamati dengan faktorial design $2^{3}$ dimana dua merupakan jumlah level dan tiga merupakan banyaknya variabel berubah sedangkan sebagai responnya: $\mathrm{Y}=$ hasil percobaan. Faktorial design $2^{3}$ ini terdapat 8 perlakuan (8 run) pengamatan. Adapun rancangan percobaan adalah:

$$
\mathrm{Y}=\text { hasil pektin }
$$

Faktorial design $2^{3}$ terdapat 8 perlakuan ( 8 run) pengamatan. Disini menggunakan 2 level yaitu satu level rendah (low level) dan level tinggi (hight level). Biasanya diberi simbu (-) untuk low level dan (+) untuk hight level.

\section{Penentuan variabel berpengaruh}

Dari perhitungan effek utama dan interaksi diatas variabel yang paling berpengaruh adalah yang mempunyai nilai mutlak yang paling benar. Dari analisis variasi (persamaan $\mathrm{Y}=\mathrm{f}(\mathrm{x})$ dapat dilihat kecenderungan-kecenderungan tiap variabel misalnya dari perhitungan effek didapat harga I maka:

- Bila I > 0 berarti perubahan harga pH dari satu menjadi 3,5 akan menaikkan hasil sebesar $\mathrm{I}_{1}$

- Bila I < 0 berarti perubahan harga pH dari 1 menjadi menurunkan hasil $\mathrm{I}_{1}$

Untuk menaikan Yield maka :

- Bila $\mathrm{I}_{1}>0$ maka $\mathrm{x}_{1}>0$ atau variabel $1>$ nilai tengahnya

- Bila $\mathrm{I}_{1}<0$ maka $\mathrm{x}_{1}<0$ atau variabel $1<$ nilai tengahnya

Variabel yang sangat berpengaruh ditentukan harga masing-masing variabel dengan melihat kecenderungan - kecenderungan tiap variabel yang diamati.

\section{HASIL DAN PEMBAHASAN}

Percobaan dilakukan dengan variabel tetap yaitu berat sampel 40 gr dengan perbandingan aseton : filtrat $=1: 2$. Sedangkan variabel berubah pada level bawah (-) suhu ekstraksi $60{ }^{\circ} \mathrm{C}, \mathrm{pH}=1$ dan waktu ekstraksi 30 menit, sedangkan pada level atas (+) suhu $100{ }^{\circ} \mathrm{C}, \mathrm{PH}=3,5$ dan waktu ekstraksi 120 menit. Kadar pektin dianalisa pada tiap run, analisis dilakukan dengan ekstraksi. Variabel yang mempunyai pengaruh paling besar terhadap proses yang diambil dari hasil perhitungan analisa variant yaitu $I_{2}$ adalah temperatur. 
Pada hasil percobaan pektin yang diperoleh dapat dilihat dalam grafik pada Gambar 1.

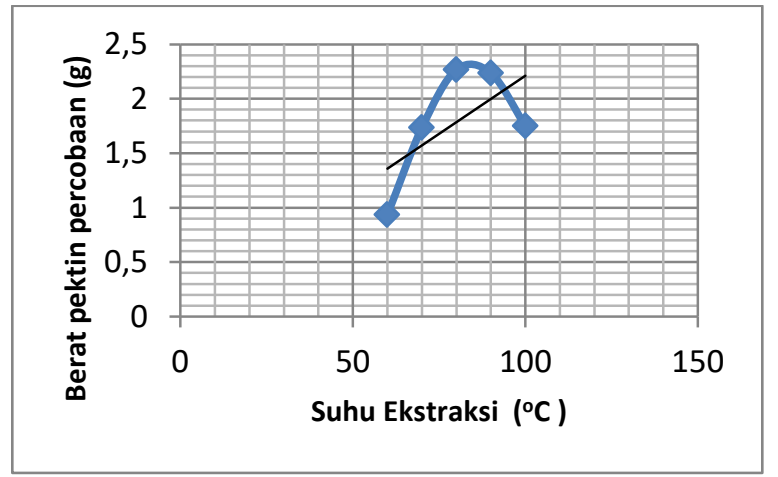

Gambar 1. Grafik hubungan antara suhu ekstraksi dengan Yield berdasarkan hasil percobaan

Berdasarkan gambar 1, dapat dijelaskan bahwa semakin tinggi suhu dalam ekstraksi semakin banyak yield yang diperoleh. Semakin tinggi suhu semakin banyak pula pektin yang larut dalam solvent. Terlihat dalam grafik pada Gambar 1 , pektin yang diperoleh sebesar 2,267 gr pada suhu $84,9^{\circ} \mathrm{C}$.

Pada hasil perhitungan pektin yang diperoleh dapat dilihat pada grafik pada Gambar 2:

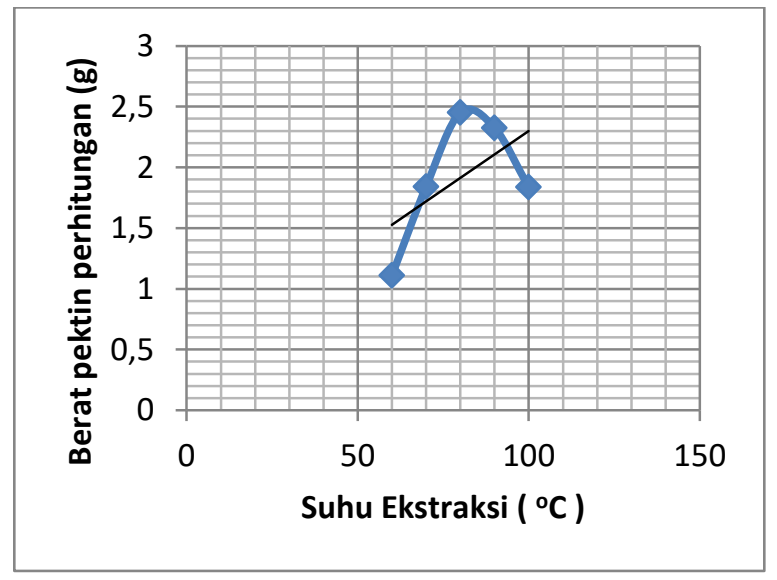

Gambar 2. Grafik hubungan antara suhu ekstraksi dengan Yield berdasarkan hasil perhitungan

Dapat di jelaskan bahwa semakin tinggi suhu dalam ekstraksi semakin banyak yield yang diperoleh. Semakin tinggi suhu semakin banyak pula pektin yang larut dalam solvent. Berdasarkan grafik pada gambar 2, pektin yang diperoleh dalam perhitungan sebesar 2,451 gr. Jika dibandingkan pektin hasil perhitungan dengan hasil percobaan mempunyai kesalahan 10,598 \% .

\section{SIMPULAN}

Dari hasil penelitian hingga dapat di tarik kesimpulan bahwa dengan bertambahnya suhu ekstraksi maka jumlah pektin yang diambil semakin banyak. Dengan bertambahnya derajat keasaman $(\mathrm{pH})$ maka jumlah pektin yang diambil semakin banyak. Dengan bertambahnya waktu ekstraksi maka jumlah pektin yang terambil semakin banyak sesuai dengan Purwoko (2011) . Sehingga pada kondisi optimal untuk pengambilan pektin dari buah tomat adalah dengan berat 40 gram, jumlah solvent $200 \mathrm{ml}$, waktu ekstraksi 30 menit, suhu ekstraksi $84,9{ }^{\circ} \mathrm{C}, \mathrm{pH}$ larutan 1 dan pada tekanan operasi 1 Atm. Kadar air dan kadar abu yang diperoleh masing-masing 76,2 \% dan 9,03\%. Dari hasil optimasi diperoleh persamaan:

$$
Y=-406,59+10,766 x-0,0668 x^{2}
$$

\section{DAFTAR PUSTAKA}

Budiyanto, A. dan Yulianingsih, 2006, Pengaruh suhu dan waktu ekstraksi terhadap karakter pektin dari ampas jeruk siam (Citrus nobilis $L)$. Balai penelitian dan pengembangan pasca panen Pertanian. Bogor

Mariaty, D., 2000, Pektin dan pemanfaatannya dalam industri pangan

Departemen Pertanian, 1977, Budi Daya tanaman Tomat, Pengendali mutu tanaman, Jakarta.

Dinas Pertanian Tanaman Pangan, 1992, Selayang Pandang Pengembangan Hortikultura di Jawa Tengah, D2/FW/XII/1992 Propinsi Daerah I Jawa Tengah, Semarang.

Muhidin, D., 2001, Papain dan Pektin, Penerbit Swadaya, Jakarta

Fitriani, V., 2003, Ekstraksi dan Karakterisasi Pectin dari Kulit Jeruk Lemon (Citrus medica Var Lemon), Skripsi, IPB, Bogor.

Garna, H., Nicholasmabon, C.,Robert, C., Cornet, K., Legros, N.H., Bernardwanthelet, and Paquot, A., 2007, Effect of Extraction 
Conditions on the Yield and Purity of Apple Pomance Pectin Precipitated but not Washed by alcohol, J.Food Science, 72 (1)

Kirk. R.E. and Otmer, D.F., 1958, Encyclopedie of Chemical Technology, Vol. 14, The Interscience Encyclopedia, Inc., New York.

Mc. Cabe, Waren L., 2005, Unit operation of Chemical Enginnering, $7^{\text {th }}$ ed., Mc. Graw Hill, Purwoko 2011 Pembuatan pektin dari buah papaya (Carica Papaya L.) sisa sadap. J. Teknik Industri Pertanian 12 (1):8-13.

Putra, I.N.K, 2010, Optimasi Proses Ekstraksi Pektin dari Buah Nangka (Artocarpus heterphyllus Lamk), J.Agritech, 30(3):1-14

Sudarmadji S., Haryono B., Suhardi, 1989, Prosedur Analisis untuk Bahan Makanan dan Pertanian, Liberty, Yogyakarta.

Willat, W.G.T., Knox, P. and Mikkelsen, 2006 Pectin; New Insights Into on Old Polymer are starting to Gel. J.Trends in Food Science and Technology, 17: 97-104. 